\title{
Impact of lockdown due to COVID-19 pandemic on groundwater salinity in Punjab, India: some hydrogeoethics issues
}

\author{
G. Krishan ${ }^{1}$ (1) N. Sudarsan ${ }^{1} \cdot$ B. S. Sidhu ${ }^{2} \cdot$ R. Vashisth $^{3}$
}

Received: 23 September 2020 / Accepted: 1 April 2021 / Published online: 13 April 2021

(c) The Author(s), under exclusive licence to Springer Nature Switzerland AG 2021

\begin{abstract}
In the present study, a total of 48 groundwater samples (13 from shallow aquifers depth $<50 \mathrm{~m}$ and 35 samples from deep aquifers in the depth range 50-200 m) were collected from three industrial dominant districts (Ludhiana, Jalandhar and Moga) of Punjab after the lockdown period and before the start of southwest monsoon in the month of June, 2020 (pre-monsoon). The values for total dissolved solids (TDS) observed in Monsoon season (August, 2020) and November-December, 2019 (post-monsoon) were compared with the values taken in June, 2020 (pre-monsoon) to see the impact of lockdown due to COVID-19 pandemic on groundwater salinity. $\sim 60 \%$ of samples were found to have TDS values more than acceptable limit $(500 \mathrm{mg} / \mathrm{l})$ before lockdown (post-monsoon season of 2019) period and after or during lockdown period (June, 2020) number of samples more than the acceptable limit $(500 \mathrm{mg} / \mathrm{l})$ reduced to $45 \%$. Average TDS values reduced by $25 \%$ in shallow aquifers after lockdown and area under TDS values in acceptable limit $(500 \mathrm{mg} / \mathrm{l})$ increased by $23 \%$ of samples as compared to the TDS values found in monsoon season of year 2019. In deeper aquifers, increase of only $3 \%$ area under TDS values in acceptable limit of $500 \mathrm{mg} / \mathrm{l}$ was found. Reductions in TDS values in shallow aquifers clearly show that there is an urgent need for proper management of salinity causing elements and regulating these to check groundwater contaminations using the holistic and hydro-geoethical approach.
\end{abstract}

Keywords COVID-19 $\cdot$ Lockdown $\cdot$ Groundwater $\cdot$ Salinity $\cdot$ Punjab $\cdot$ Hydrogeoethics

\section{Introduction}

Water plays an important role in human health, but has been adversely affected due to the contaminants added from minerals of geological origin and/or from industrial and agricultural activities (Nollet 2000). In most of the countries, higher incidences of diseases and mortality due to unsafe drinking water are the foremost concerns (WHO 2011). Demand for fresh water due to increasing population and developmental activities in various sectors such as agriculture, domestic and industrial is continuously increasing (Raju et al. 2011). Due to the inadequate supply of fresh surface water, people from semi-arid regions depend on groundwater for their needs

G. Krishan

drgopal.krishan@gmail.com

National Institute of Hydrology, Roorkee, Uttarakhand, India

2 PSFC, Mohali, Punjab, India

3 Department of Soil and Water Conservation, Chandigarh, Punjab, India
(Shankar and Sanjeev 2008; Gleeson et al. 2010) while in India, $85 \%$ of rural population exclusively depend on it (Kinzelbach et al. 2003).

Groundwater, the largest storage of fresh water is a vital constituent of hydrological cycle (Todd 1959). In India, groundwater quality has been deteriorating and constantly been questioned from health point of view (Garg et al. 2009; Alam 2014). The rivers carrying chemical effluents and toxic elements from various point and non-point sources degrade the quality of groundwater which is further degraded by the industrial wastes, unorganized use of pesticides and fertilizers, (Beg and Ali 2008). Many researchers have agreed that improper agricultural practices will lead to groundwater pollution (Mikayilov and Acar 1998; Ahmad and Khurshid 2019; Narsimha et al. 2013) including the groundwater salinity (Krishan 2019) which is primarily due to the high concentrations of salts and other elements including trace metals contributed from industrial and agricultural wastes.

Agriculture is widely recognized as an important source of water contamination (FAO and IWMI 2018). These include unsustainable cropping systems, waste from 
livestock and aquaculture as well as misuse of fertilizers (including manure applications), pesticides, bacteria, microorganisms and antimicrobial residues via leaching, surface and subsurface runoff from croplands and grazing systems pollute water resources (FAO 2020; Hallema et al. 2020).

Punjab, an agrarian state of the India is facing problems of groundwater depletion and contamination happening naturally and/or through agricultural inputs and industrial wastes (Lapworth et al. 2015, Lapworth et al. 2017; MacDonald et al. 2016). Groundwater salinity issues are on the rise in southwestern districts of Punjab (Krishan et al. 2020c, 2021) and there is an apprehension that it might extend to central Punjab.

There is a notable environmental recovery due to the direct and indirect impacts of COVID-19 pandemic. Satellite data are showing significant reductions of $\mathrm{NO}_{2}$ (nitrogen dioxide) over major cities in China, Europe, USA, and India (NASA Earth Observatory 2020); in Venice, Italy, canal water appeared visibly clearer (Link 2020). Impact of COVID-19 on water resources has been reported by Krishan (2020) and its impact during and post-COVID-19 by Krishan and Kulshrestha (2020) where emphasis is laid on hydro-geoethical and holistic approaches to achieve sustainable governance working on the experiences of experts from different disciplinary domains (Marone and Bohle 2020).

COVID-19 is an unprecedented challenge for India; its large population and the economy's dependence on informal labor make lockdowns and other social distancing measures hugely disruptive. Even though the government has announced lockdown with the relaxations in farming, implementation was disrupted due to labor shortage.

The effects of reduced point source (Industrial sites) inputs on surface water quality might become evident within a matter of weeks while the effect of reduced nonpoint source (agriculture) inputs in groundwater could take much longer to measure. This encourages the need for this study which has been conducted in three main industrial districts of Punjab occupying the central position in the state to assess the impact of lockdown due to COVID-19 pandemic on groundwater salinity.

\section{Study area}

The study is mainly focused on the three main industry dominant districts of Punjab: Ludhiana, Jalandhar and Moga have 12,11 and 5 administrative blocks, respectively. The study area lies in the central region of Punjab state in India, comprising an area of about $8559 \mathrm{~km}^{2}$. The geographical co-ordinates are; $75^{\circ} 15^{\prime}$ to $76^{\circ} 27^{\prime}$ east Longitude and $30^{\circ}$ $33^{\prime}$ to $31^{\circ} 37^{\prime}$ north Latitude and the study area surrounded by Kapurthala, Hoshiarpur and SBS Nagar districts in the north and bounded by Firozpur, Faridkot, Bathinda, Barnala, Sangrur, Fatehgarh sahib and Rupnagar districts in south.

Geologically, the study area forms a part of Indo-Gangetic alluvium of Quatenary period due to the deposits from Indus river system (Bonsor et al. 2017). The Sutlej River flows across the study area from east to west dividing the BistDoab in the north and Malwa region in the south. The map representing the study area is shown in the Fig. 1.

\section{Topology}

The slope of the surface influences the runoff conditions. The hilly regions are intrinsic of high slope terrain, which accounts in increased runoff rate thus reducing the infiltration. On the other hand, plain terrains are intrinsic of low slope and accounts in reduced runoff rate, significantly increasing the rate of infiltration. The steeper slope indicates the minimum groundwater recharge and the gentle slope offers maximum groundwater recharge (Duan et al. 2016; Rajaveni et al. 2015).

As the slope greatly depends on the elevation of the area, the topography should be known to determine this characteristic. The topology map was extracted from the Shuttle Radar Topography Mission (SRTM) - DEM of 1-arc second (Fig. 2). From the elevation map of the study area, it is clear that the variation of slope is gentle due to the non-occurrence of hilly terrain. Meanwhile, surface elevation varies along the flow of the river Sutlej, higher elevation in the east to lower elevation in the west of the study area.

\section{Geomorphology}

The external geological processes influence the geometry of the landform. The different geological processes such as chemical reactions, repeated freezing and thawing, seismic effects and weathering due to wind and water, dominates the shape of the surface (Rajaveni et al. 2015; Ganesh et al. 2017).

The geomorphology of the study area has been downloaded from the Geological Survey of India website (Bhukosh-GSI) and mapped with the help of ArcGIS 10.5. Four major landforms were mapped in the geomorphology map (Fig. 3). It is observed that the general landform of the study area is a alluvial plain and the flood plains were present in the sides of the Sutlej river. Additionally, Aeolian dunes were found only in the western part Jalandhar district.

\section{Hydrogeology}

The study of groundwater conditions relies on the geological mapping and type of lithology present beneath. The different geological units which affect the groundwater flow and the quality should be paid attention (Ramaiah et al. 2012). 
Fig. 1 Study area showing river and canal network

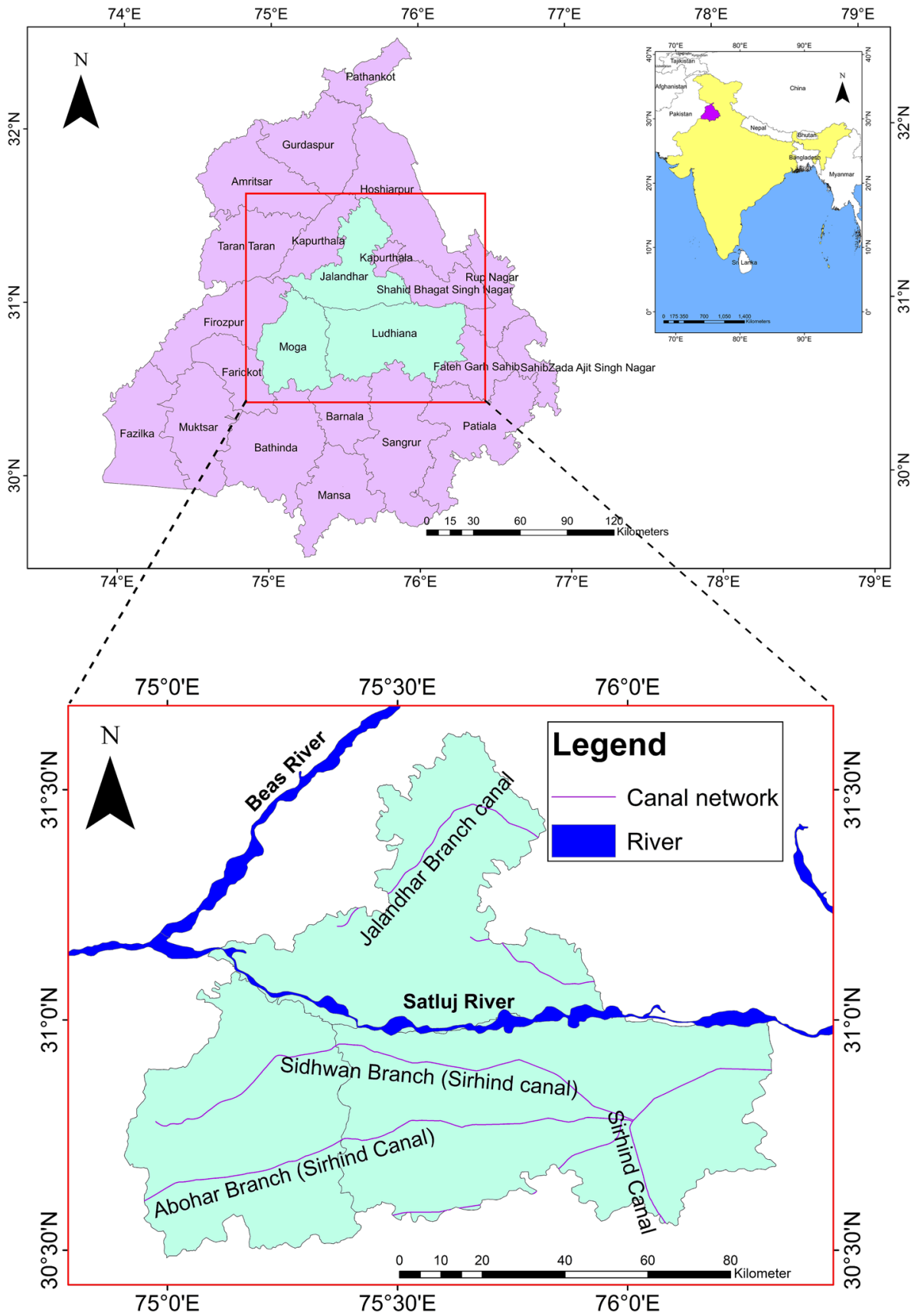

Study area forms Indus alluvial plains having multi aquifer systems upto depth of $300 \mathrm{~m}$ with alternate layers of sand and clay as shown in aquifer geometry map (Fig. 4) (CGWB 2017). The porosity of the rock decides the storage capacity of the rock and also the groundwater flow inside the aquifer depends upon the hydraulic conductivity or permeability of the rocks (Sedhuraman et al. 2014).

The lithology of the study area has been downloaded from the Geological Survey of India website (BhukoshGSI). Generally, the area is covered with the oxidized silt-clay with kankar. Moreover, the yellowish brown loose sands were found distributed all along the study area in small patches but mostly in the Jalandhar district. The Sutlej River was classified as Grey sand, slit and clay and the flood plains around the river were classified with the Grey Micaceous sand, silt and clay. The finals maps were prepared in ArcGIS 10.5 software.

\section{Rainfall}

Groundwater recharge of the shallow aquifer purely depends on the rainfall which infiltrates through the porous soil. The water table fluctuation highly correlates with the amount of precipitation (Halder et al. 2020). The amount of rainfall 


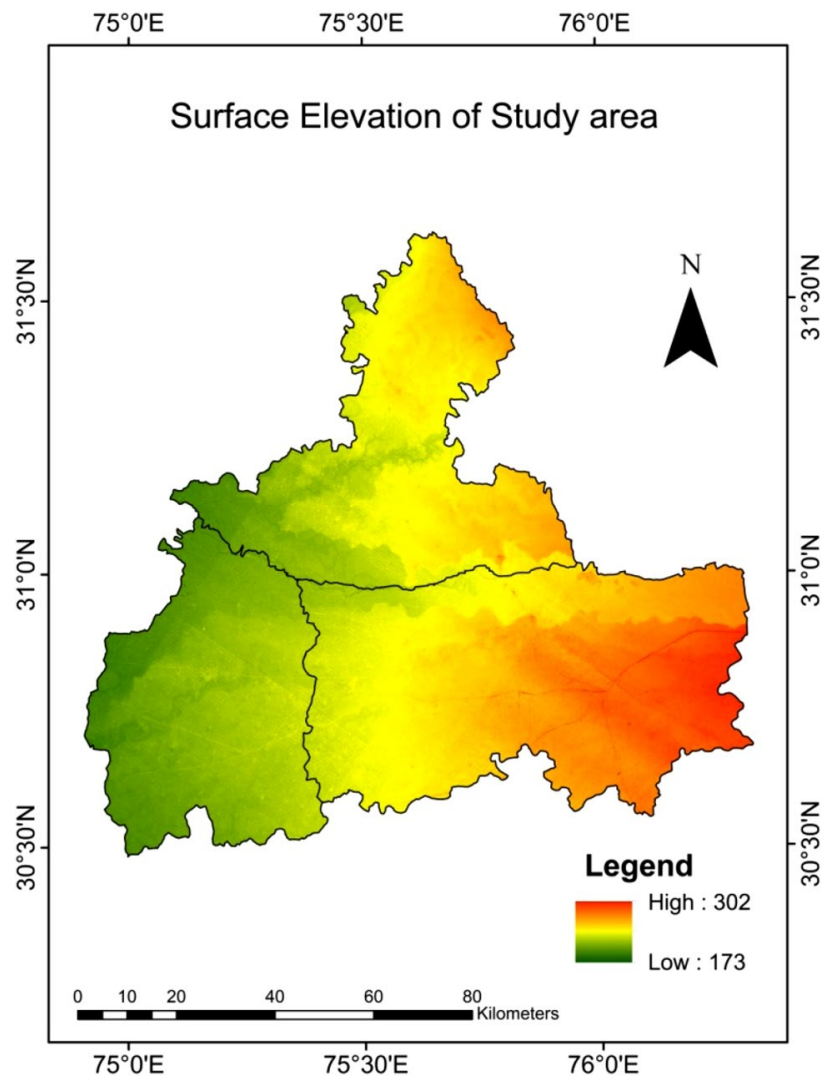

Fig. 2 Surface elevation map of study area

recorded during the study period is necessary to correlate with the salinity changes in the shallow aquifer (Krishan et al. 2020a, 2020b). The data from Indian Meteorological Department (IMD) were downloaded from India-WRIS website.

\section{Materials and methods}

Groundwater availability in an area depends on various factors such as topology of the land surface, geological formation, geomorphology, rainfall conditions, soil type, etc. while the quality of groundwater depends upon both the natural and anthropogenic sources. The causes of salinity fluctuation can be predicted only with the elevation, geology, geomorphology and rainfall data.

\section{Collection of water samples}

The sampling was carried out in the study area with defined intervals between the sample points. Grids were prepared using GIS at the latitude interval of $5^{\prime} \mathrm{N}$ and longitude interval of $5^{\prime} \mathrm{E}$, such as it makes $10 \mathrm{~km} \times 10 \mathrm{~km}$ sampling. Totally 48 sampling locations were selected widely across

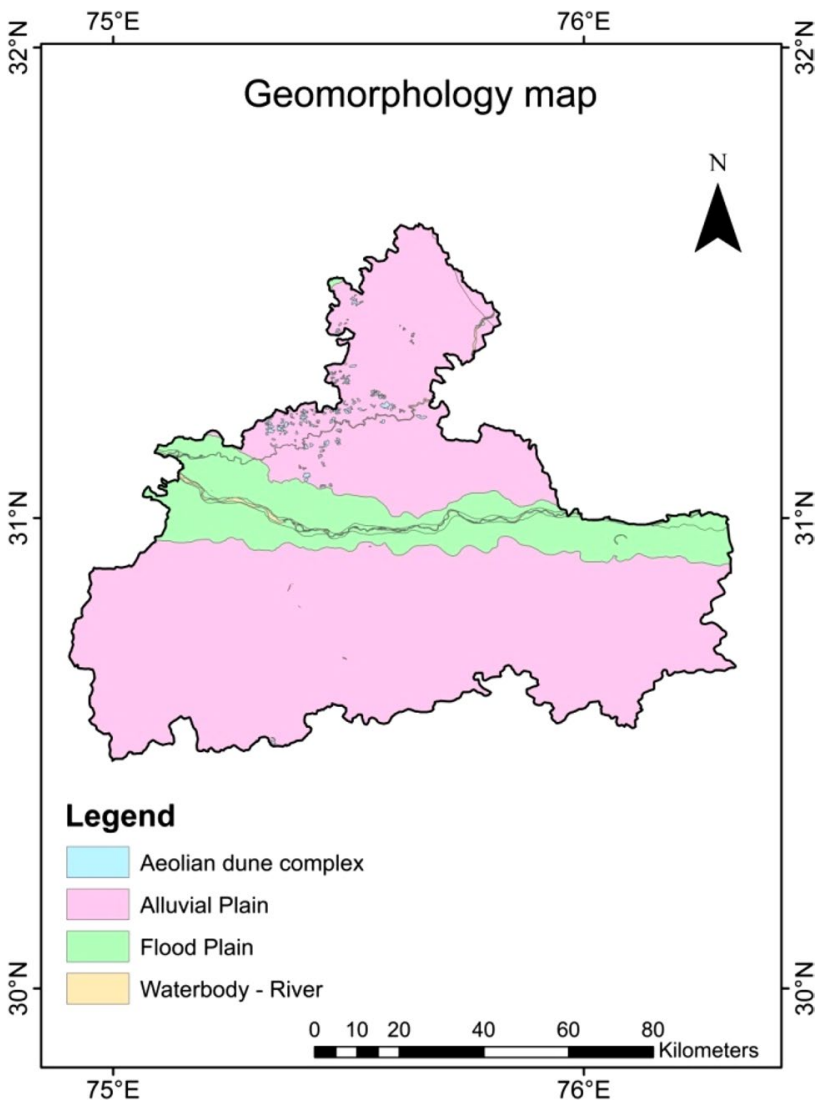

Fig. 3 Geomorphology map of study area

the study area and effective sampling was done August, 2019 for monsoon season and in November December, 2019 for post-monsoon season. These two samplings were carried out before lockdown period. After lockdown, sampling was carried out in the month of June, 2020 (pre-monsoon season). 13 groundwater samples from shallow depth upto $50 \mathrm{~m}$ and 35 samples from depth range 50-200 m were collected from the bore wells/ hand pump or open wells as per the availability. The sampled locations were shown in the gridded map (Fig. 5). Groundwater samples were collected after thoroughly flushing the water for at least $15 \mathrm{~min}$ or until temperature measurements indicated that all onsite storage was purged and water originated from the well bore or aquifer. The samples were collected in acid washed LDPE (lowdensity polyethylene) Tarson bottles.

\section{Analysis of pH and TDS}

The $\mathrm{pH}$ of an aqueous solution is the measure acidic or basic capacity. The $\mathrm{pH}$ of a solution can be determined using the concentration of hydronium ion concentration in the solute. Initially the probe and glassware was rinsed with distilled or de ionized water and then probe (hand held portable Eutech $\mathrm{pH}$ meter) calibrated against $\mathrm{pH}$ buffer solution 4, 7 and 10 


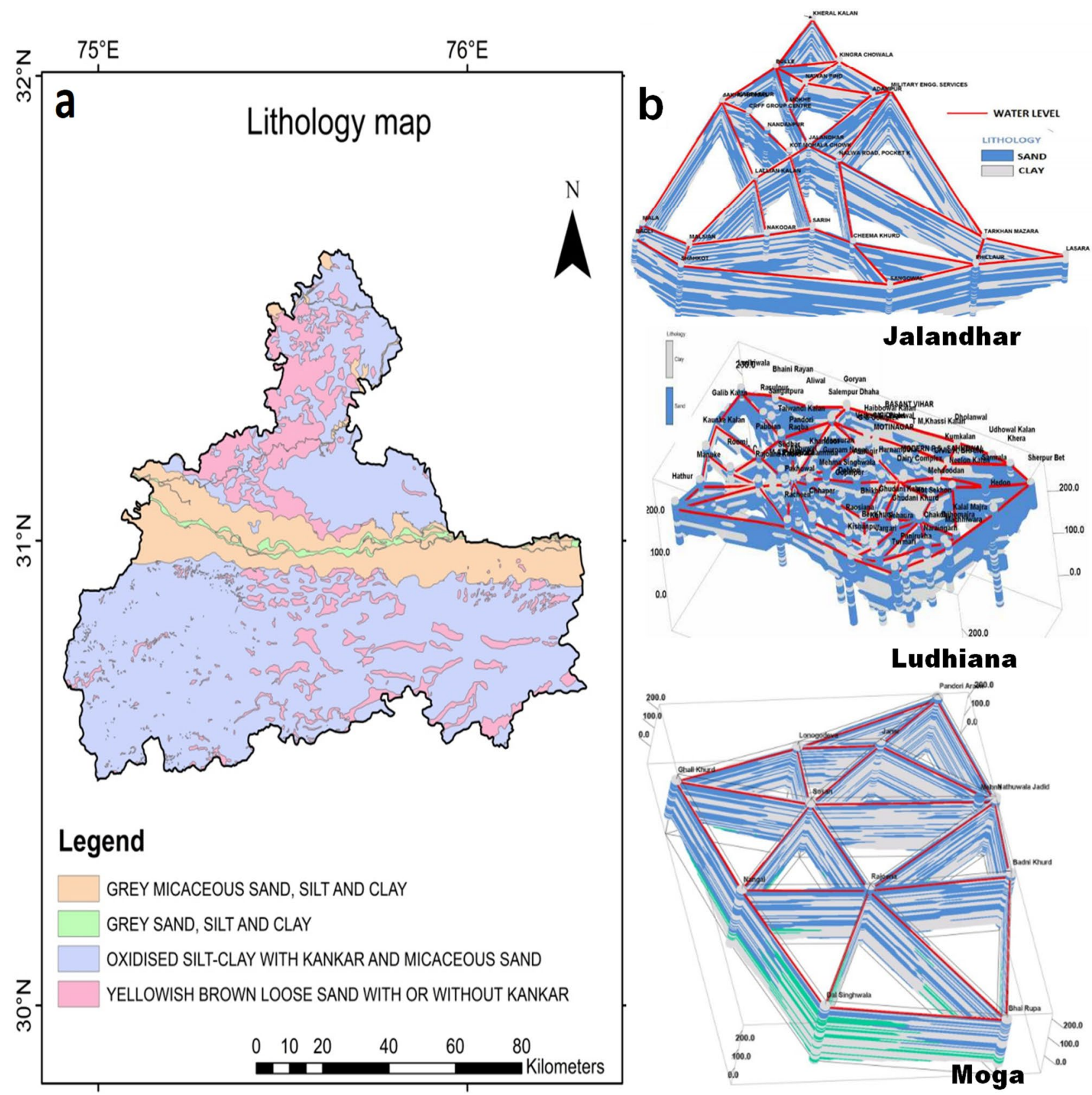

Fig. 4 Geology map (a) and aquifer geometry (b) of study area

at $25{ }^{\circ} \mathrm{C}$. $\mathrm{pH}$ measured insitu by immersing the probe in groundwater samples (Al-Qawati et al. 2018).

Conductivity is a measure of water's capability to pass electrical flow. This ability is directly related to the concentration of ions in the water. Conductivity probe (multiparametric Eutech's PCSTester 35, error $\pm 10 \mu \mathrm{S} / \mathrm{cm}$ i.e. $\sim 1 \%$ ) is rinsed with distilled water and cleaned with tissue paper and calibrated by standard solutions. After calibrating probe was once again rinsed with distilled water and cleaned with tissue paper. Then the probe was immersed in samples for EC measurements. All measurements were made in situ. Later, Electrical Conductivity (EC) converted into Total dissolved solids (TDS) by an empirical formula (Eq. 1) (Rusydi 2018; Ali et al. 2012).

Total dissolved soilds $=0.65 \times$ electrical conductivity. 
Fig. 5 Sampling locations with grid

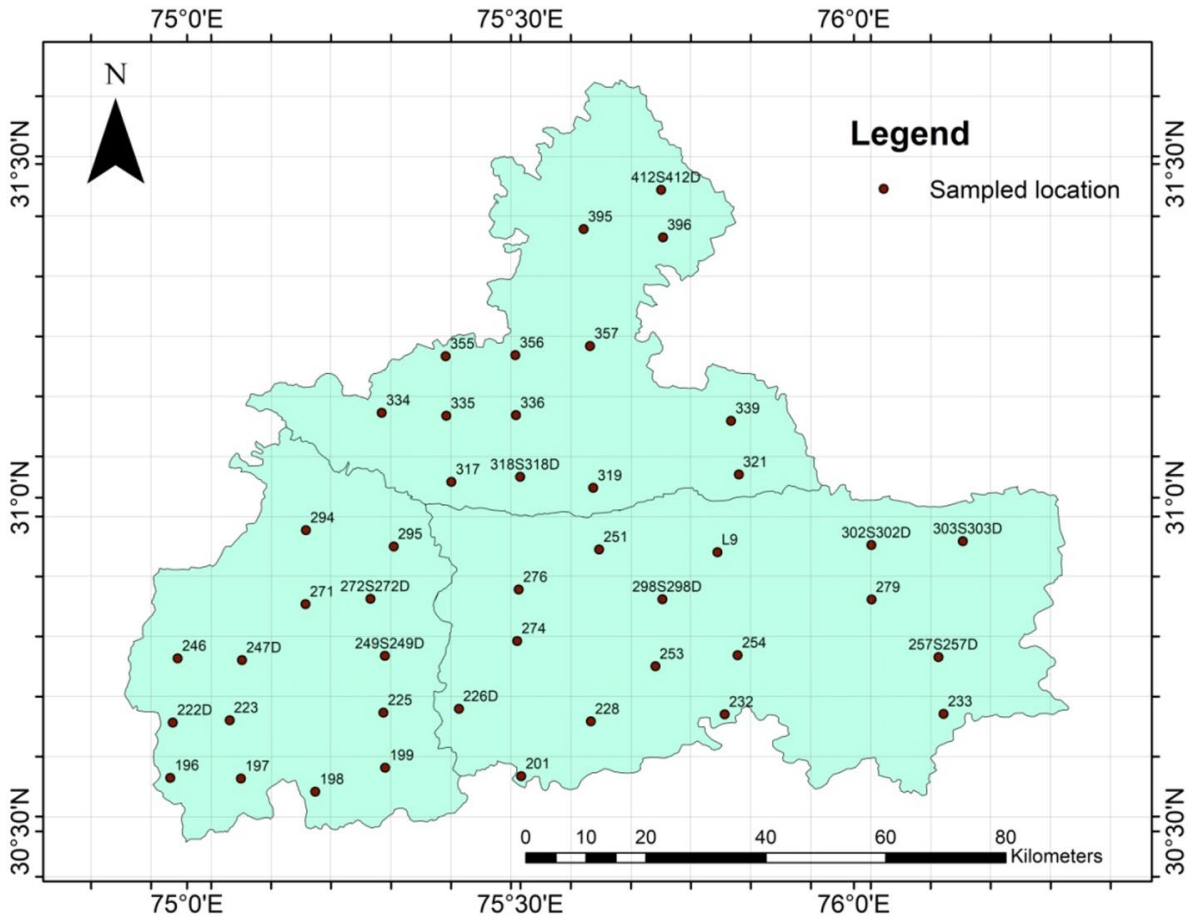

sample points. Weights are computed by the inverse of the distance from an observation to an estimate (Burrough and McDonnell 1998; Setianto and Triandini 2013; Honarbakhsh et al. 2019; Selvam et al. 2014; Pande and Moharir 2018).

$V_{i}=\frac{\sum_{j=1}^{n} \frac{V_{j}}{d_{i j}^{p}}}{\sum_{j=1}^{n} \frac{1}{d_{i j}^{p}}}$

where

$V_{\mathrm{i}}=i$ th unknown value

$n=$ number of points taken to obtain the unknown value

$V_{j}=j$ th known value

$d_{i j}=$ distance between the $i$ th unknown value and the $j$ th known value

$p=$ power tributed sample points. Estimates of IDW (Eq. 2) interpolation are the weighted averaged values of surrounding

Fig. 6 Monthly cumulative rainfall (Nov 2018-June 20)

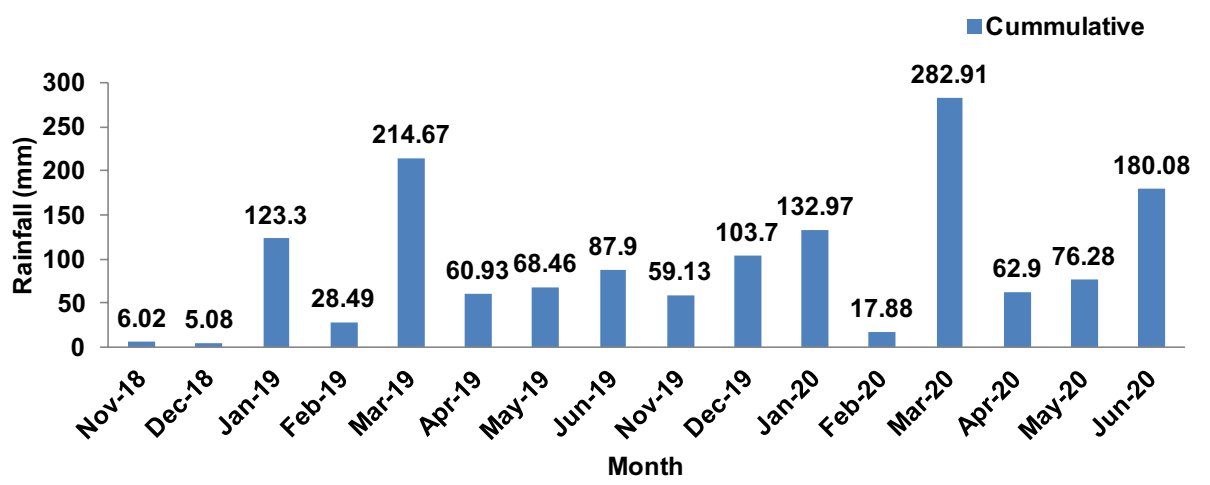




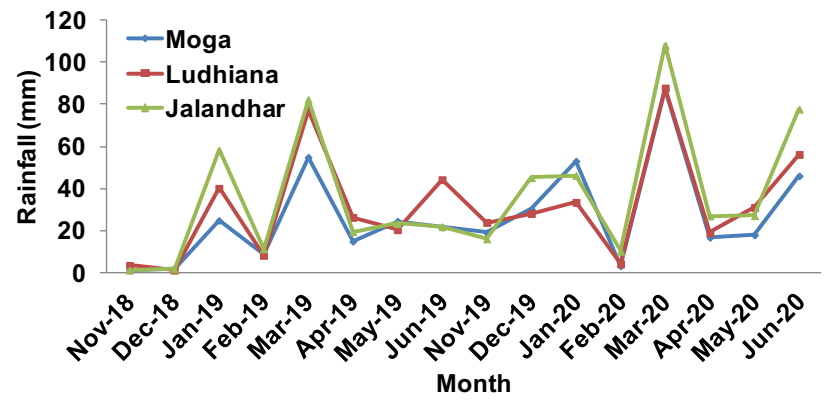

Fig. 7 District-wise monthly rainfall variations

\section{Results and discussion}

Depending on the availability of data and resources, this study concentrates on the use of surface elevation, geomorphology, geology, rainfall and sample analysis results.

\section{Rainfall}

The IMD rainfall data of the study period from November, 2018 to June, 2020 were analysed. The monthly average rainfall was found $94 \mathrm{~mm} /$ month for the study period where the average annual rainfall of the Punjab state is more than $640 \mathrm{~mm}$. Monthly cumulative rainfall of the study area was plotted in a bar chart (Fig. 6). From the bar chart, it is also observed that, study area has a highest rainfall in the month on March, 2020 with $282.91 \mathrm{~mm}$ and lowest rainfall $5.08 \mathrm{~mm}$ was recorded in the month of Dec, 2018.

The rainfall behavior patterns of three states were plotted (Fig. 7), it is obvious that it follows a similar pattern in monthly fluctuations. But when comparing the cumulative rainfall between the districts, Jalandhar ranks first with $358 \mathrm{~mm}$ followed by Ludhiana with $284 \mathrm{~mm}$ and at last by Moga with $274 \mathrm{~mm}$. The well-defined rainy period of the study area is during the southwest monsoon (July to September), $90 \%$ of the rainfall occurs during this period (CGWB 2017). There is not much rainfall during the study period.

\section{pH}

According to Indian standards specifications (IS 10500: 2012), the $\mathrm{pH}$ value of drinking water should be in the range of 6.5-8.5. The $\mathrm{pH}$ value of the water samples for shallow aquifers varies from 6.9 to 8.1 with a mean of 7.6 in monsoon season; 7.2-8.2 with a mean of 7.7 in postmonsoon season and from 7.1 to 8.3 with the mean of 7.7 pre-monsoon season while for deep aquifers $\mathrm{pH}$ varies from 7.1 to 8.9 with a mean of 7.7 in monsoon season; 7.2-8.6 with a mean of 7.8 in post-monsoon season and from 7.1 to 8.9 with the mean of 7.7 pre-monsoon season (Table 1). In

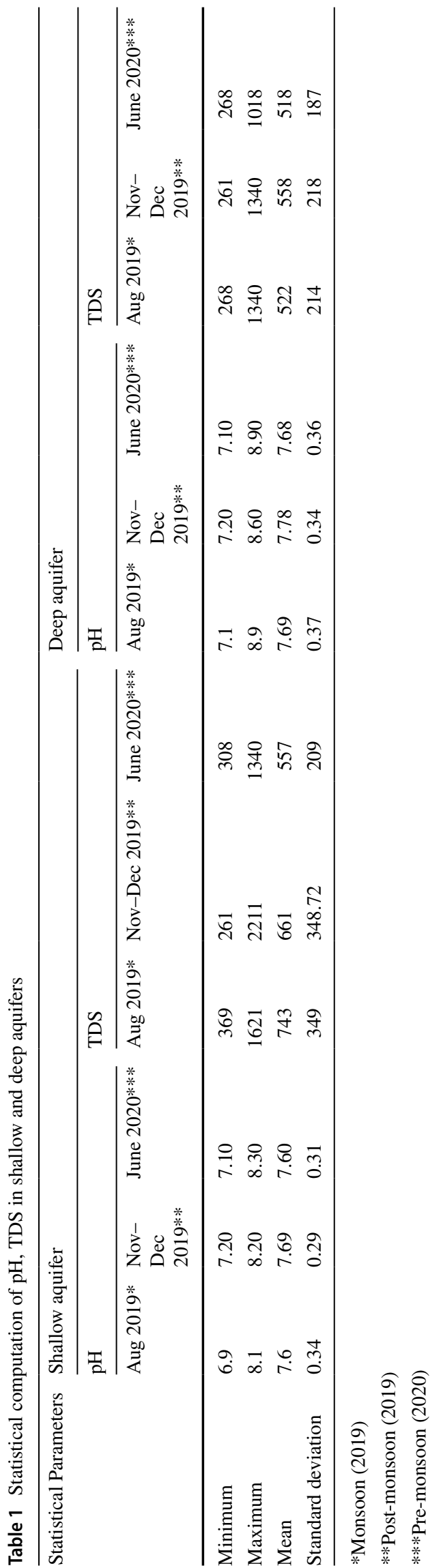


all three seasons, only $1 \%$ of the samples were found to be above the acceptable range of 6.5-8.5.

\section{Total dissolved solids (TDS)}

The total dissolved solid (TDS) concentration is directly proportional to the salinity content of the water, assuming all the dissolved solids are of metal salts only. Many researchers have proved that TDS is an effective indicator of water quality.

According to Bureau of Indian Standards (BIS) (IS 10500: 2012), the acceptable limit of TDS for drinking purpose is $500 \mathrm{mg} / \mathrm{l}$. The statistical parameters of TDS from the sample analysis were tabulated in the Table 1 . From the mean and maximum values, it is evident that the maximum salinity $743 \mathrm{mg} / \mathrm{l}$ was found in the monsoon season in the shallow aquifers. Out of 48 samples collected, $60 \%$ of samples were found to have TDS values more than acceptable limit $(500 \mathrm{mg} / \mathrm{l})$ before lockdown (post-monsoon season of 2019) period and after or during lockdown period (June, 2020) number of samples more than the acceptable limit $(500 \mathrm{mg} / \mathrm{l})$ reduced to $45 \%$. There was also slight reduction in percentage of samples $(6 \%)$ with TDS values exceeding $1000 \mathrm{mg} / \mathrm{l}$ after lockdown as compared to the period before lockdown.

\section{Spatio-temporal distribution of salinity}

The analysed samples were interpolated by the IDW technique and spatio-temporal variability maps were prepared using ArcGIS 10.5 software. The salinity distribution before and after lockdown for both shallow and deep aquifers were mapped separately and shown in Figs. 8 and 9 respectively (Li et al. 2015).

The TDS variation in maps have been shown by separating TDS values into 6 classes, as, $<250 \mathrm{mg} / 1,250-500 \mathrm{mg} / \mathrm{l}$, 500-1000 mg/l, 1000-1500 mg/1, 1500-2000 mg/l and $>2000 \mathrm{mg} / \mathrm{l}$. The area occupied by each class was calculated. In deep aquifer only minor changes were found in TDS values due to the lockdown and TDS variation in deep aquifer were classified into three classes (Fig. 8) since there was no sample found with TDS value $>1500 \mathrm{mg} / \mathrm{l}$. The area of classes was found to be equal in second and third classes. The TDS range of 1000-1500 mg/l (fourth class) was found to be spread around $61.10 \mathrm{~km}^{2}$ before lockdown and after lockdown it reduced to $1.57 \mathrm{~km}^{2}$.

Shallow aquifers are influenced greatly by the external factors such as rainfall, pesticides, industrial wastes, etc. From the TDS values of the shallow aquifer (Fig. 9), it is found that salinity was high before lockdown and it reduced after lockdown period. Before lockdown, the TDS variation was
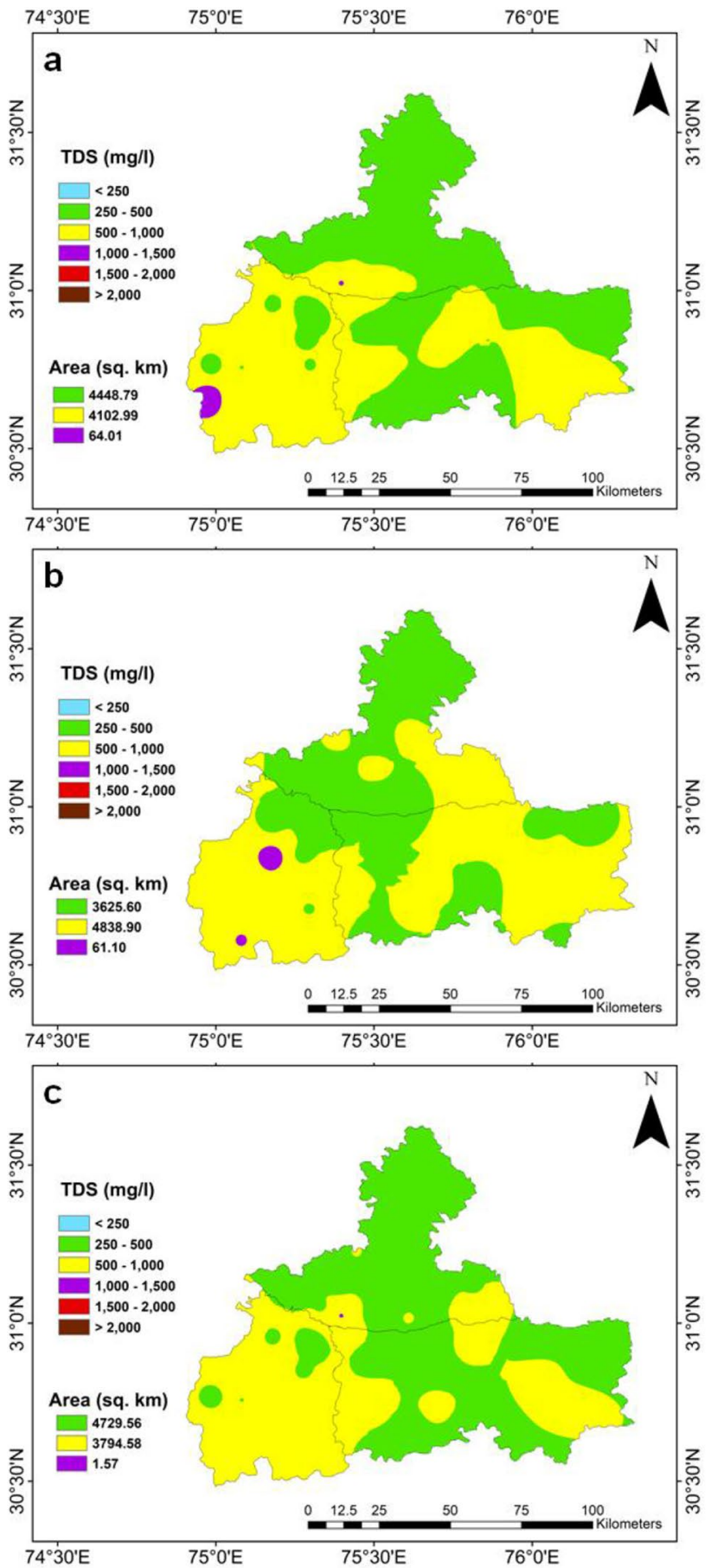

Fig. 8 Salinity variation in deep aquifers a June, 2019 b NovemberDecember, 2019 and c June, 2020

higher as $11.64 \mathrm{~km}^{2}$ of area was having TDS $>2000 \mathrm{mg} / \mathrm{l}$, $30.44 \mathrm{~km}^{2}$ of area was having TDS $>1500 \mathrm{mg} / \mathrm{l}$ and $273.73 \mathrm{~km}^{2}$ of area was having TDS $>1000 \mathrm{mg} / \mathrm{l}$. There is a drastic change after lockdown in shallow aquifers with no samples was found with TDS $>1500 \mathrm{mg} / \mathrm{l}$ TDS and only 


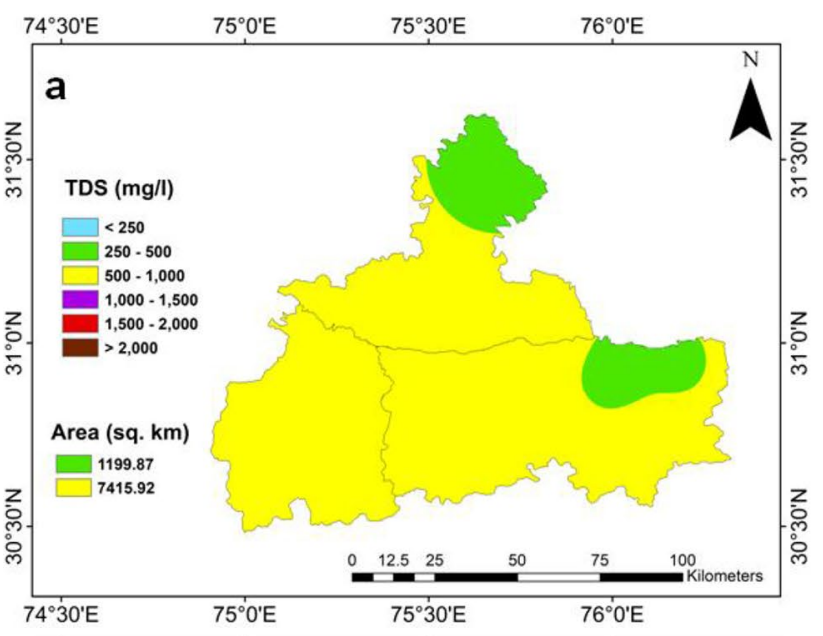

can be ruled out as the lithology of the study area does not contribute to dilution of groundwater and it is also evident that the rainfall was not the cause for the dilution of salinity since the observations were recorded during pre-monsoon period of 2020. Ludhiana and Jalandhar districts are well known for industrial activities and it is found that due to the non-functioning of these industries and other related activities probably there may be minimum contamination from industrial effluents into groundwater.

\section{Conclusion}

- It is concluded that there is less influence of geology, geomorphology and rainfall in the shallow aquifer of study area for the period studied.

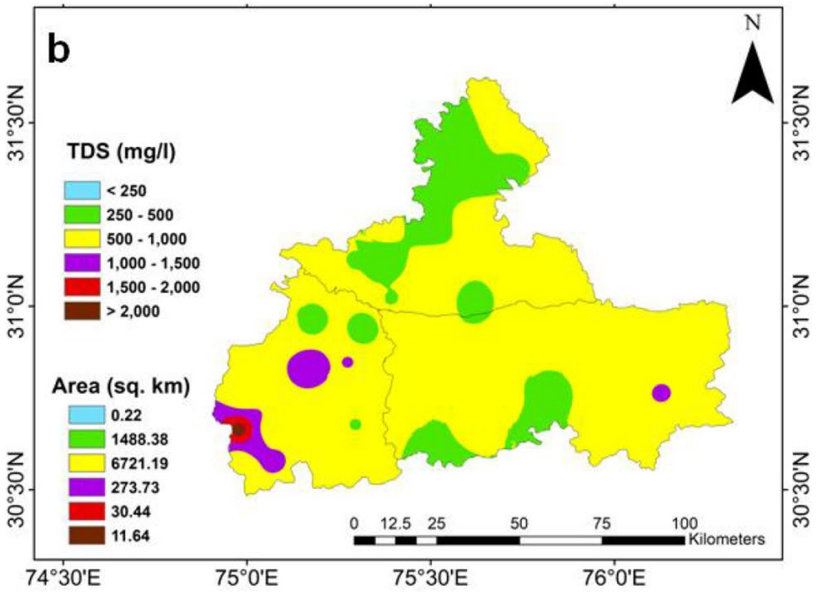

- It is evident from that there was no industrial functioning during the lockdown.

- From the TDS maps, it is found that the salinity in the shallow aquifers reduced due to non-working of industrial activities.

- There is a need of efficient and proper handling of agricultural inputs like pesticides and fertilizers and by regulating the disposal of industrial wastes for saving groundwater from contaminations using the holistic and hydro-geoethical approach.

Acknowledgements Funding received from Punjab state farmers and farm workers commission is duly acknowledged. Authors thanks Chairman PSFC and Director NIH for all support and encouragement.

\section{Declarations}

Conflict of interest Authors declare there are no conflicts of interests.

\section{References}

Ahmad S, Khurshid S (2019) Hydrogeochemical assessment of groundwater quality in parts of the Hindon River basin, Ghaziabad, India: implications for domestic and irrigation purposes. SN ApplSci $1: 151$

Akintorinwa O, Okoro O (2019) Combine electrical resistivity method and multi-criteria GIS-based modeling for landfill site selection in the Southwestern Nigeria. Environ Earth Sci 78:162

Fig. 9 Salinity variation in shallow aquifers a June, 2019 b November-December, 2019 and c June, 2020

$46.11 \mathrm{~km}^{2}$ of area was having TDS more than $1000 \mathrm{mg} / 1$ which was $315.81 \mathrm{~km}^{2}$ before lockdown. The TDS values after lockdown reduced $<500 \mathrm{mg} / 1$ in $3183.56 \mathrm{~km}^{2}$ area, with $>100 \%$ increase in area from $1488.38 \mathrm{~km}^{2}$ before lockdown.

In general, the change in the groundwater salinity in aquifers due to the external factors like geology or rainfall 
Al-Qawati M, El-Qaysy M, Darwesh N et al (2018) Hydrogeochemical study of groundwater quality in the west of SidiAllalTazi, Gharb area Morocco. J Mater Environ Sci 9(1):293-304

Beg KR, Ali S (2008) Chemical contaminants and toxicity of Ganga river sediment from up and down stream area at Kanpur. Am J Environ Sci 4(4):362

BIS (Bureau of Indian Standards) (2012) Specification for drinking water IS 10500:2012 New Delhi India.

Bonsor HC, MacDonald AM, Ahmed KM et al (2017) Hydrogeological typologies of the Indo-Gangetic basin alluvial aquifer South Asia. Hydrogeol J 25(5):1377-1406. https://doi.org/10.1007/ s10040-017-1550-z

Burrough PA, McDonnell RA (1998) Principles of geographical information systems. Oxford University Press, Oxford

CGWB (2017) Aquifer mapping and management plan north western region. Central Groundwater Board, Ministry of Water Resources Government of India, Chandigarh

Duan H, Deng Z, Deng F, Wang D (2016) Assessment of groundwater potential based on multicriteria decision making model and decision tree algorithms. Math ProblEng. https://doi.org/10.1155/ 2016/2064575

Elumalai V, Brindha K, Sithole B, Lakshmanan E (2017) Spatial interpolation methods and geostatistics for mapping groundwater contamination in a coastal area. Environ SciPollut Res. https://doi. org/10.1007/s11356-017-8681-6

FAO (2020) The state of World Fisheries and Aquaculture http:// www.fao.org/publications/sofia/2020/en/. Accessed 20 Sept 2020

FAO and IWMI (2018) More people, more food, worse water? a global review of water pollution from agriculture. Food and Agriculture Organization of the United Nations Rome, and International Water Management Institute on behalf of the Water Land and Ecosystems research program of the CGIAR Colombo, 2018

Ferchichi H, Hamouda MF, Farhat B, Mammou A (2018) Assessment of groundwater salinity using GIS and multivariate statistics in a coastal Mediterranean aquifer. Int J Environ SciTechnol. https:// doi.org/10.1007/s13762-018-1767-y

Ganesh KM, Sankar J, Boyidi S, Murthy Y (2017) Integration of geology and geomorphology for groundwater occurrence in a hard rock region, Nakrekal basin, Nalgonda District, Telangana State, using remote sensing and GIS techniques. Int J ApplInnoEng Manage 6:10

Garg VK, Suthar S, Singh S, Sheoran A, Garima M, Jai S (2009) Drinking water quality in villages of southwestern Haryana, India: assessing human health risks associated with hydrochemistry. Environ Geol 58:1329-1340

Gleeson T, VanderSteen J, Sophocleous MA et al (2010) Groundwater sustainability strategies Nat Geosci 3(6):378

Goyal SK, Chaudhary BS, Singh O, Sethi GK, Thakur PK (2010) GIS based spatial distribution mapping and suitability evaluation of groundwater quality for domestic and agricultural purpose in Kaithal district, Haryana state, India. Environ Earth Sci 61(8):1587-1597

Halder S, Roy M, Roy M (2020) Analysis of groundwater level trend and groundwater drought using standard groundwater level Index: a case study of an eastern river basin of West Bengal, India. SN ApplSci 2:507

Hallema D, Rabinne F, McNulty S (2020) Pandemic spotlight on urban water quality. Ecol Process 9:22

Honarbakhsh A, Azma A, Ostovari Y, Mousazadeh M, Eftekhari M (2019) Hydro-chemical assessment and GIS-mapping of groundwater quality parameters in semi-arid regions. J Water Supply Res Technol Aqua 68(7):509-522
Jat MK, Khare D, Garg PK (2009) Urbanization and its impact on groundwater: a remote sensing and GIS-based assessment approach. Environmentalist 29:17-32

Kinzelbach W, Bauer P, Siegfried T, Brunner P (2003) Sustainable groundwater management-problems and scientific tools. Episodes 26(4):279-284

Krishan G (2019) Groundwater Salinity. Curr World Environ 14(2):186-188

Krishan G (2020) Water sector scientific imperatives for COVID-19. Curr World Environ 15(1):05-07

Krishan G, Kulshrestha U (2020) During and post COVID-19: Challenges in water sector and ethical issues. In: Geoethics and groundwater management congress organized by International Association of Hydro-geologists (IAH) and International Association for Promoting Geoethics (IAPG). during May 18-22, 2020 at Porto-Portugal

Krishan G, Prasad G et al (2020a) Identifying the seasonal variability in source of groundwater salinization using deuterium excessa case study from Mewat, Haryana, India. J HydrolReg Stud 31:100724. https://doi.org/10.1016/j.ejrh.2020.100724

Krishan G, Ghosh NC et al (2020b) Understanding stable isotope systematics of salinity affected groundwater in Mewat, Haryana, India. J Earth SystSci 129:109. https://doi.org/10.1007/ s12040-020-1380-6

Krishan G, Bisht M, Ghosh NC, Prasad G (2020c) Groundwater salinity in north west of India a critical appraisal. In: Singh R, Shukla $\mathrm{P}$, Singh P (eds) Environmental processes and management. Water Science and Technology Library, Springer, Cham

Krishan G, Vashisht R, Sudarsan N et al (2021) Groundwater salinity and isotope characterization: a case study from South-West Punjab, India. Environ Earth Sci 80(4):169. https://doi.org/10. 1007/s12665-021-09419-7

Lapworth DJ, MacDonald AM, Krishan G, Rao MS, Gooddy DC, Darling WG (2015) Groundwater recharge and age-depth profiles of intensively exploited groundwater resources in northwest India. Geophys Res Lett 42(18):7554-7562. https://doi.org/10.1002/ 2015GL065798

Lapworth DJ, Krishan G, MacDonald AM, Rao MS (2017) Groundwater quality in the alluvial aquifer system of northwest India: new evidence of the extent of anthropogenic and geogenic contamination. Sci Total Environ 599-600(2017):1433-1444

Li W, Wang M, Liu L, Yan Y (2015) Assessment of long term evolution of groundwater hydrochemical characteristics using multiple approaches: a case study in Cangzhou, Northern China. Water 7:1109-1128. https://doi.org/10.3390/w7031109

Link D (2020) Fact check: COVID-19 crisis has not created decreased long-term human environmental impact. USA Today. Mar 25. https://www.usatoday.com/story/news/factcheck/2020/ 03/25/fact-check-coronavirus-crisisbenefiting-environment/ 2908300001/ Accessed 17 Apr 2020

MacDonald A, Bonsor H et al (2016) Groundwater depletion and quality in the Indo-Gangetic Basin mapped from in situ observations. Nat Geosci 9:762-766

Marone E, Bohle M (2020) Geoethics for nudging human practices in times of pandemics. Sustainability 12(18):7271. https://doi. org/10.3390/su12187271

Mikayilov FD, Acar B (1998) Toprak ekosistemlerinde kirleticilerin tas, 1 ım mekanizmasının incelenmesi ve modellenmesi (Investigation and modelling of contaminant's movement processes within the soil ecosystems). C, ev Kor 28:20-23

Narsimha A, Sudarshan V, Swathi P (2013) Groundwater and its assessment for irrigation purpose in Hanmakonda area, Warangal district, Andhra Pradesh, India. Int J Res Chem Environ 3(2):196-200

NASA Earth Observatory (2020) Airborne nitrogen dioxide plummets over China. https://www.earthobservatory.nasa.gov/ 
images/146362/airborne-nitrogendioxide-plummets-over-china Accessed 17 Apr 2020.

Nollet L (2000) Handbook of Water Analysis. Marcel Dekker, New York

Ojo JS, Olorunfemi MO, Bayode S, Akintorinwa OJ, Omosuyi GO, Akinluyi FO (2014) Constraint map for landfill site selection in Akure Metropolis, Southwestern Nigeria. Ife J Sci 16:405-416

Pande C, Moharir K (2018) Spatial analysis of groundwater quality mapping in hard rock area in the Akola and Buldhana districts of Maharashtra India. Appl Water Sci. https://doi.org/10.1007/ s13201-018-0754-2

Rajaveni SP, Brindha K, Elango L (2015) Geological and geomorphological controls on groundwater occurrence in a hard rock region. Appl Water Sci. https://doi.org/10.1007/ s13201-015-0327-6

Raju JN, Shukla UK, Prahlad R (2011) Hydrogeochemistry for the assessment of groundwater quality in Varanasi: a fast-urbanizing center in Uttar Pradesh, India. Environ Monit Assess 173:279-300

Ramaiah SN, Gopalakrishna GS, Vittala SS, Najeeb KMd (2012) Geomorphological mapping for identification of ground water potential zones in hard rock areas using geo-spatial information- a case study in Malur Taluk, Kolar District, Karnataka, India. Nat Environ PollutTechnol 11(3):369-376

Rusydi A (2018) Correlation between conductivity and total dissolved solid in various type of water: a review, IOP conference series: Earth and environmental science, vol 118, Global Colloquium on GeoSciences and Engineering 2017, 18-19 October 2017, Bandung, Indonesia

Sedhuraman M, Revathy SS, Suresh BS (2014) Integration of geology and geomorphology for groundwater assessment using Remote
Sensing and GIS techniques. Int J Innovative Res Sci Eng Technol 3(3):10203-10211

Selvam S, Manimaran G, Sivasubramanaian P, Balasubramanaian N, Seshunarayana T (2014) GIS-based evaluation of water quality index of groundwater resources around Tuticor in coastal city, South India. Environ Earth Sci 71:2847-2867

Setianto A, Triandini T (2013) Comparison of kriging and Inverse Distance Weighted (IDW) interpolation methods in lineament extraction and analysis. J Southeast Asian ApplGeol 5(1):21-29

Shankar BS, Sanjeev L (2008) Assessment of water quality index for the groundwater of an industrial area in Bangalore India. Environ EngSci 25(6):911-916

Shanmugasundharam A, Kalpana G, Mahapatra SR, Sudharson ER, Jayaprakash M (2015) Assessment of groundwater quality in Krishnagiri and Vellore districts in Tamil Nadu India. Appl Water Sci. https://doi.org/10.1007/s13201-015-0361-4

Tiwari K, Goyal R, Sarkar A (2017) GIS-based spatial distribution of groundwater quality and regional suitability evaluation for drinking water. Environ Process 4:645-662

Todd DK (1959) Groundwater hydrology. Wiley, New York

World Health Organization WHO (2011) Guidelines for drinkingwater quality, 4th edn. WHO Press, Geneva

Publisher's Note Springer Nature remains neutral with regard to jurisdictional claims in published maps and institutional affiliations. 